\title{
Insulin-like growth factor-I expression is not increased in the retina of diabetic $\mathrm{BB} / \mathrm{W}$-rats*
}

\author{
S. Charkrabarti ${ }^{1}$, A. Ghahary ${ }^{2}$, L.J. Murphy ${ }^{2}$ and Anders A.F. Sima ${ }^{3}$ \\ Neuropathology Research Laboratories, 'Department of Pathology and ${ }^{2}$ Departments of Physiology and Internal Medicine, \\ University of Manitoba. Winnipeg, Manitoba. Canada and ${ }^{3}$ Departments of Pathology and Internal Medicine and Michigan \\ Diabetes Research and Training Center, University of Michigan, Ann Arbor, Michigan, U.S.A.
}

(Received 13 May 1991)

(Accepted 7 July 1991)

\section{Summary}

A combination of immunocytochemistry, in situ hybridization and ligand binding were used to investigate the localization of IGF-I and its receptor in the retina of diabetic and non-diabetic BB/W-rats. Immunocytochemical localization revealed the presence of IGF-I in retinal pigment epithelium, ganglion cells, Muller cell processes and in microvessels. In most sites immunoreactivity was increased in the diabetic retina compared to that of non-diabetic $\mathrm{BB} / \mathrm{W}$-rats. In microvessels, however, immunoreactivity was decreased in diabetes. In situ hybridization using an antisense IGF-I riboprobe provided evidence of IGF-I synthesis in all retinal layers with a similar grain density in diabetic and non-diabetic rats. Autoradiographic localization of IGF-I receptors, using [ ${ }^{125}$ I]-IGF-I binding, demonstrated a diffuse localization in all retinal layers, with an increase in diabetic animals. These findings suggest that IGF-I synthesis is not altered in the diabetic retina, and that the increased immunoreactivity of IGF-I detectable in the various layers of the retina from diabetic rats may be due to an increased uptake of blood-derived IGF-I suggested by increased receptor density in diabetic rats.

Key words: Insulin-like growth factor-I; Retina; BB/W-rats

\section{Introduction}

Trophic factors probably play a role in the pathogenesis of diabetic complications [1]. In the diabetic retina, several trophic factors released into the extracellular space have been identified

Correspondence to: A. Sima, Michigan Diabetes Research and Training Center, The University of Michigan, 1331 East Ann Street Bldg., Ann Arbor, MI 48109-0580, U.S.A.

* Presented in part at the Scheie Eye Institute Symposium, 1990, University of Pennsylvania, Philadelphia, PA, U.S.A. and may be important in promoting neovascularization [1]. A number of investigators have reported that insulin-like growth factor-I (IGF-I) expression is diminished in various tissues in experimental diabetic rats, whereas systemic hyperinsulinism induced by exogenous insulin administration augments IGF-I expression in certain tissues [2-4]. In clinical diabetes, however, conflicting results have been obtained with respect to IGF-I levels in vitreous and serum from diabetic patients $[5,6]$. 
Insulin, IGF-I and -II are present in the central nervous system and exhibit important effects on neuronal tissue growth, survival and regeneration [7]. Although the IGF-I gene is expressed by the retina [8], it is not known to what extent retinal IGF-I is affected by diabetes. IGF-I receptors have been demonstrated in the retinal pigment epithelium (RPE), retinal rod cells, and the neural retina [9-11]. Moreover IGF-I binds to specific receptors on retina derived endothelial cells and pericytes and stimulates their DNA synthesis in vitro [12], which may suggest a potential role for IGF-I in retinal neovascularization. It is, however, not clear to what extent retinal IGF-I represents localized synthesis or uptake of exogenous blood-derived IGF-I.

In the present communication we report on the presence and synthesis of IGF-I and the localization of IGF-I receptors in the retina. Further, we attempt to compare the abundance of retinal IGF-I and its receptors in diabetic and nondiabetic rats.

\section{Materials and Methods}

\section{Animals}

Five spontaneously diabetic male BB/W-rats with a diabetes duration of 3 months, and age- and sex-matched non-diabetic BB/W-rats were used in this study. (NIH Colony, Department of $\mathrm{Pa}$ thology, University of Massachusetts. Worcester, MA, U.S.A.). Animals were maintained in air-filtered metabolic cages with a $12 \mathrm{~h}$ off and on light cycle and given commercial rat chow (Wayne Lab Blox-F-6, Wayne Feed Division, Chicago, IL, U.S.A.) and water ad libitum. The animals were monitored with respect to body weight and blood glucose levels as previously described $[13,14]$.

\section{Tissue collection}

Animals were anesthetized with intraperitoneal sodium pentobarbital $(50 \mathrm{mg} / \mathrm{kg}$ of body weight) and killed by whole body perfusion with $4 \%$ paraformaldehyde in $50 \mathrm{mmol} / \mathrm{l}$ phosphate buffer ( $\mathrm{pH}$ 7.4). The eyes were dissected and processed for paraffin embedding. Five micron thick sections on aminoalkylsialane coated slides were used for immunocytochemistry, in situ hybridization and autoradiographic localization of IGF-I receptors.

\section{Immunocytochemistry}

Rabbit anti-IGF-I antibody (kindly provided by Drs. J.J. von Wyk and L. Underwood) at a dilution of $1: 100$ was used for overnight incubation at $4{ }^{\circ} \mathrm{C}$. Equally thick tissue sections were stained as previously described [4] by employing a biotin-streptavidin amplified system (Stravigen kit, Biogenex Laboratories, San Ramon, CA, U.S.A.). Negative controls included sections incubated with non-immune serum, or preabsorbed antiserum incubated for $24 \mathrm{~h}$ in $4^{\circ} \mathrm{C}$ with excess IGF-I. The experimental conditions were identical for diabetic and control animals.

\section{Immunodot analysis}

Individual retinal samples from five diabetic and five non-diabetic animals were homogenized in $3 \mathrm{vol}$ of $5 \mathrm{mmol} / 1$ Tris- $\mathrm{HCl}(\mathrm{pH} \mathrm{7.4)}$, centrifuged at $45,000 \times \mathrm{g}$ for $40 \mathrm{~min}$, and the supernatants were collected. Two dilutions of the homogenate containing 10 and $40 \mu \mathrm{g}$ of protein were applied to a nitrocellulose membrane with a 96-well manifold. All samples were analyzed in one assay using previously described techniques [15]. Briefly, after blocking nonspecific proteins by incubation with $5 \%$ skim milk, the membranes were incubated with rabbit anti-IGF-I antibody $(1: 100$ in Tris buffered saline, pH 8.0 containing $0.02 \%$ Tween 20). Membranes were washed, and the presence of IGF-I was revealed by incubation with anti-IgG alkaline phosphate substrate (Promcga, Mississauga, ONT, Canada). The slope of the line of best fit for the relationship between the optical density area (independent variable, determined by densitometry), and protein concentration, (dependent variable), was determined for each sample and designated arbitrary units of IGF-I immunoreactivity. 


\section{In situ hybridization}

Sections were deparaffinized and processed for in situ hybridization as previously described [16]. Hybridization was performed at $45^{\circ} \mathrm{C}$ in a solution containing $50 \%$ formamide, $0.3 \mathrm{mmol} / \mathrm{l}$ $\mathrm{NaCl}, \quad 20 \mathrm{mmol} / \mathrm{l}$ Tris- $\mathrm{HCl} \quad(\mathrm{pH} 8.0), \quad 1 \times$ Denhardt's solution, $1.0 \mathrm{nmol} / \mathrm{l}$ EDTA, $0.005 \%$ ssDNA, $0.005 \%$ poly (A), $20 \mathrm{mmol} / 1$ mercaptoethanol, $0.05 \%$ yeast tRNA and $10 \%$ dextran sulphate. Riboprobes were prepared from a template constructed by subcloning an IGF-I cDNA into the pGEM-3Z vector. T7 and Sp6 polymerases were used for the generation of sense and antisense riboprobes [17]. Autoradiography was performed using Kodak NTB2 tracking emulsion. Slides were exposed for 5-10 days prior to development of the photographic emulsion.

\section{$\left.\int^{125} I\right]-I G F-I$ binding to retinal sections}

Retinal sections were deparaffinized and receptor localization was carried out as previously described [18] using [ $\left.{ }^{125} I\right]-I G F-I$. Binding was achieved by the addition of $10 \mathrm{mmol} / \mathrm{l}$ HEPES buffer ( $\mathrm{pH} 7.6$ ) containing $0.5 \%$ bovine serum albumin, $0.025 \%$ bacitracin, $0.0125 \% \mathrm{~N}$-ethylmaleimide, $100 \mathrm{Kallikrein}$ inhibitor unit $/ \mathrm{ml}$ aprotinin and $0.64 \mathrm{nmol} / \mathrm{l}\left(4 \times 10^{5} \mathrm{cpm}\right)\left[{ }^{125} \mathrm{I}\right]-\mathrm{IGF}-\mathrm{I}$. Excess unlabelled IGF-I (300 $\mathrm{ng})$ was added to
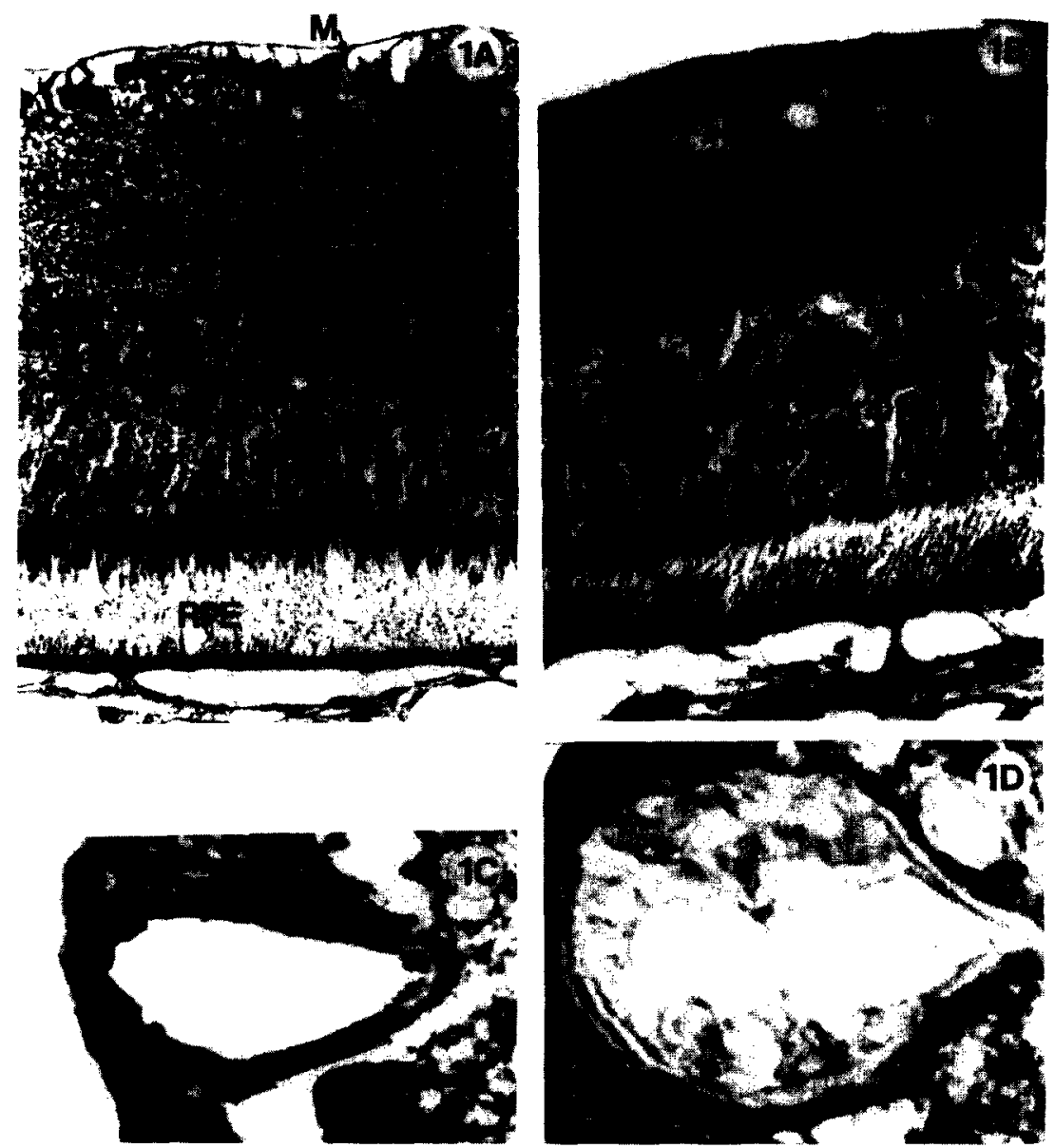

Fig. 1. Retinal micrographs showing IGF-I immunoreactivity in (A) non-diabetic BB-rat and (B) diabetic BB-rat. Microvessels from ' $A$ ' and ' $B$ ' are shown in ' $C$ ' and ' $D$ ', respectively. Note diminished immunostaining of endothelial cells in ' $D$ ' compared to ' $\mathrm{C}$ '. $\mathrm{RPE}=$ retinal pigment epithelium, $\mathrm{G}=$ ganglion cell, $\mathrm{M}=$ Muller cell process. 
TABLE 1

Retinal IGF-I and IGF-I receptors

\begin{tabular}{|c|c|c|c|}
\hline & $\begin{array}{l}\text { IGF-I immunoreactivity } \\
\text { (Arbitrary units) }\end{array}$ & IGF-I mRNA* & IGF-I receptors* \\
\hline $\begin{array}{l}\text { Control } \\
\qquad(n=5)\end{array}$ & $\begin{array}{l}0.005 \pm 0.002 \\
\text { ns }\end{array}$ & $\begin{array}{l}26.2 \pm 1.8 \\
\text { ns }\end{array}$ & $\begin{array}{l}52.5 \pm 1.9 \\
P<0.01\end{array}$ \\
\hline $\begin{array}{l}\text { Diabetic } \\
\quad(n=5)\end{array}$ & $0.010 \pm 0.003$ & $27.6 \pm 0.4$ & $75.3 \pm 5.5$ \\
\hline
\end{tabular}

* Expressed as number of grains in a circle of $1 \mathrm{~cm}$ radius drawn on micrographs with a total magnification of $1600 \times$.

determine nonspecific binding. After $20 \mathrm{~h}$ of incubation the slides were exposed to Kodak NTB 2 emulsion and autoradiography was performed.

Autoradiographic sections were photographed with a final magnification of 1600 times for quantification of grain density. Random circles of $1 \mathrm{~cm}$ radius were drawn on various retinal layers, and the number of grains within each circle was counted. Mean numbers of grains/circle from each layer were determined and the mean number of grains/circle/retina calculated.

\section{Slatistical analysis}

Data were expressed as mean \pm SEM and analyzed by Student's $t$-test.

\section{Results}

Diabetic animals showed marked hyperglycemia $(23.4 \pm 2.4 \mathrm{mmol} / \mathrm{l}$ vs $5.1 \pm 0.2 \mathrm{mmol} / \mathrm{l}$ in controls), polyuria, glycosuria and occasional ketonuria. At death, diabetic rats weighed $418.8 \pm 21.1 \mathrm{~g}$ vs control rats who weighed $516.2 \pm 7.6 \mathrm{~g}$.

\section{Immunocytochemistry}

In non-diabetic retinas IGF-I was localized to the retinal pigment epithelium (RPE), ganglion cells, Muller cell processes and areas opposing the inner and outer limiting membranes. The outer plexiform layer and some cells of the inner nuclear layer showed positive immunoreactivity. The

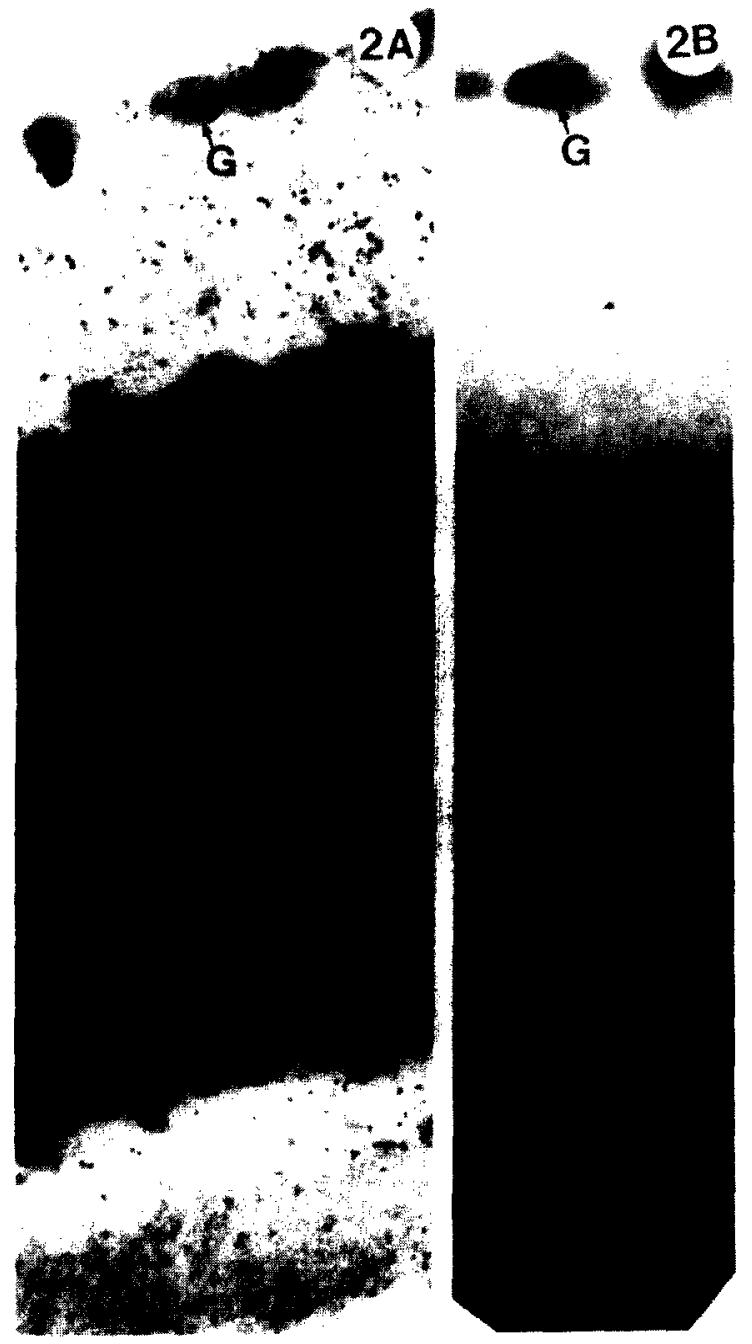

Fig. 2. Autoradiographs following in situ hybridization of retina with IGF-I riboprobes from a normal rat with antisense probe (A) and with sense probe in (B). $G=$ ganglion cell. 
outer nuclear layer showed no staining (Fig. 1). Positive staining was observed in the walls of retinal microvessels including both endothelial cells and pericytes (Fig. 1). In diabetic retinas the distribution of IGF-I appeared to be similar, however, the staining intensity was increased compared to controls (Fig. 1). Retinal glial and neuronal components as well as the RPE showed increased immunoreactivity in diabetic rats, whereas in retinal microvessels the immunoreactivity of endothelial cells was diminished (Fig. 1). No staining was observed in sections incubated with non-immune serum or with preabsorbed antiserum (data not shown).

Immunodot analysis showed a nonsignificant doubling of IGF-I immunoreactivity in the retinal extracts of diabetic rats compared to that of the controls (Table 1).
In non-diabetic retinas, autoradiographic signals following antisense IGF-I riboprobe hybridization showed a diffuse distribution in all retinal layers (Fig. 2). A similar distribution was observed in diabetic retinas. Only minimal hybridization was detected with the sense riboprobe (Fig. 2). Quantification of grain density revealed no difference between diabetic and control animals, (Table 1).

Specific binding of $\left[{ }^{125} \mathrm{I}\right]-\mathrm{IGF}-\mathrm{I}$ was found in all retinal layers suggesting a widespread distribution of IGF-I receptors in the retina (Fig. 3). The density of grains, was significantly higher in retinas of diabetic rats compared to control retinas (Fig. 3, Table 1).

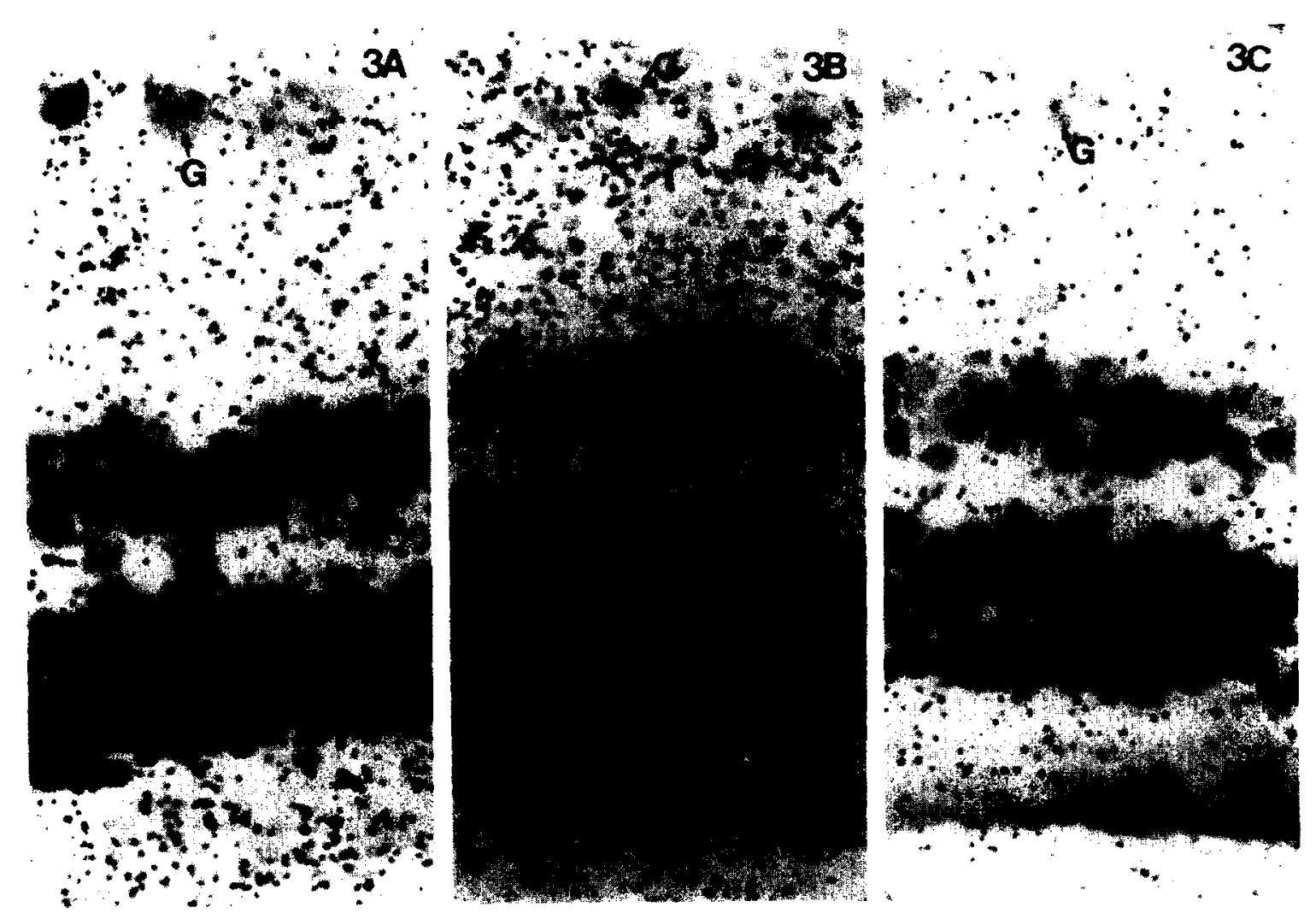

Fig. 3. Autoradiographs of retinas following receptor binding with [ $\left.{ }^{25} \mathrm{I}\right]-\mathrm{IGF}-\mathrm{I}$ in (A) non-diabetic BB-rat and (B) diabetic rat. Incubation with unlabelled IGF-I together with [ $\left.{ }^{125} \mathrm{I}\right]-\mathrm{IGF}$-I served as controls (C). Note increased grain density in 'B' compared to 'A'. 


\section{Discussion}

In the present study we have demonstrated the presence of IGF-I in the RPE, neuronal, and glial components of the normal retina as well as an increase in IGF-I immunoreactivity of these cell constituents in the retina of diabetic $\mathrm{BB} / \mathrm{W}$-rats. Surprisingly, endothelial cells of retinal capillary walls exhibited a decreased IGF-I immunoreactivity in diabetic rats. Composite retinal IGF-I was nonsignificantly increased in diabetic $\mathrm{BB} / \mathrm{W}$ rats.

This distribution of IGF-I immunoreactivity in the retina is similar to that of insulin and the localization of IGF-I receptors is consistent with recent data describing their presence in the RPE and in the neural retina $[11,19,20]$. Retinal IGF-I receptors have characteristics similar to those of insulin receptors and are more concentrated in the non-photoreceptor region of the retina [21]. In situ hybridization revealed a diffuse distribution of signals suggesting IGF-I synthesis by Muller cells, although we cannot exclude the possibility that IGF-I might be synthesized by other retinal cell components as well. Aldose reductase and insulin mRNA has been demonstrated in Muller cells [19,22]. Since both aldose reductase mRNA and protein content are increased in diabetic rat retinas [23] and IGF-I synthesis appears to be unchanged, these findings suggest, that IGF-I is not affected by an increased activity of the polyol pathway in the diabetic retina and that different mechanisms are probably involved in the regulation of these two genes.

IGF-I levels are elevated in serum and the vitreous from diabetic patients with proliferative retinopathy [5]. Some investigators have demonstrated a transient elevation of serum IGF-I during the early phases of neovascularization or during intensive insulin therapy with continuous subcutaneous insulin infusion [6,24]. Increased IGF-I in diabetic vitreous could possibly reflect increased IGF-I synthesized by retina. However, in the present study of diabetic BB/W-rats displaying the preretinopathic stage of retinal changes, increased IGF-I immunoreactivity, in the absence of increased IGF-I mRNA suggests increased uptake of IGF-I, possibly facilitated by a defect in the blood-retinal barrier, rather than an increase in locally synthesized IGF-I. This hypothesis is supported by the demonstration of increased [ $\left.{ }^{125} \mathrm{I}\right]$-IGF-I binding in the retina of diabetic $\mathrm{BB} / \mathrm{W}$-rats. In contrast, retinal microvessels demonstrated decreased immunoreactivity in diabetic BB/W-rats. How these findings, suggesting a downregulation of IGF-I receptor activity on diabetic retinal endothelial cells, can be reconciled with enhanced in vitro DNA synthesis by the same cells in response to IGF-I [12] remains to be investigated.

\section{Acknowledgements}

This study was supported in part by grants from Medical Research Council of Canada (MT10673, MA10674) and USPHS Research grant RO1- (DK 43884-01) to Dr. Sima. Dr. Charkrabarti is a recipient of a post-doctoral fellowship from Diabetes Canada.

\section{References}

1 Glaser, B.M. (1988) Extracellular modulating factors and the control of intraocular neovascularization. Arch. Ophthalmol. 106, 603-607.

2 Murphy, L.J. (1988) Impaired estrogen induced uterine insulin-like growth factor-I gene expression in the diabetic rat. Diabetologia 31, 842-847.

3 Fagin, J.A., Roberts, C.T., LeRoth, D. and Brown, A.T. (1989) Coordinate decrease of tissue insulin-like growth factor I posttranscriptional alternative mRNA transcripts in diabetes mellitus. Diabetes 38, 428-434.

4 Murphy, L.J., Ghahary, A. and Chakrabarti, S. (1990) Expression of insulin-like growth factor-I in the rat aorta: regulation by insulin. Diabetes 39, 657-663.

5 Grant, M., Russell, B., Fitzgerald, C. and Merimee, T.J. (1986) Insulin-like growth factors in vitreous: studies in control and diabetic subjects with neovascularization. Diabetes 35, 416-420.

6 Hyer, S.L., Sharp, P.S., Brooks, R.A., Burrin, J.M. and Kohner, E.M. (1989) A two year follow-up study of serum insulin-like growth factor-I in diabetics with retinopathy. Metabolism 38, 586-589. 
7 Baskin, D.G., Wilcox, B.J., Figlewicz, D.P. and Dorsa, D.M. (1988) Insulin and insulin-like growth factors in the CNS. Trends Neurosci. 11, 107-111.

8 Danias, J. and Stylianopoulou, F. (1990) Expression of IGF-I and IGF-II genes in the adult rat eye. Curr. Eye Res. 9, 379-386.

9 Hunt, R.C., Davis, A.A., Dewey, A. and Haskell, J. (1987) Transferrin and insulin-like growth factor-I receptors on retinal pigment epithelial cells. Invest. Ophthalmol. Vis. Sci. 28 (Suppl.), 225 (Abstract).

10 Zick, Y., Spiegel, A.M. and Sagi-Eisenberg, R. (1987) Insulin-like growth factor I receptors in retinal rod outer segments. J. Biol. Chem. 262, 10259-10264.

11 Ocrant, I., Valentino, K.L., King, M.C., Wimpy, T.H., Rosenfeld, R.G. and Baskin, D.G. (1989) Localization and structural characterization of insulin-like growth factor receptors in mammalian retina. Endocrinology 125, 2407-2413.

12 King, G.L., Goodman, A.D., Buzney, S., Moses, A. and Kahn, C.R. (1985) Receptors and growth promoting effects of insulin and insulin-like growth factors on cells from bovine retinal capillaries and aorta. J. Clin. Invest. $75,1028-1036$.

13 Sima, A.A.F., Bouchier, M. and Christensen, H. (1983) Axonal atrophy in sensory nerves of the diabetic BB-Wistar rat. A possible early correlate of human diabetic neuropathy. Ann. Neurol. 13, 264-272.

14 Charkrabarti, S., Ma, N. and Sima, A.A.F. (1989) Reduced number of anionic sites in association with glomerular basement membrane thickening in diabetes. Diabetologia 32, 826-828.

15 Ghahary, A., Luo, J., Gong, Y., Charkrabarti, S., Sima, A.A.F. and Murphy, L.J. (1989) Increased renal aldose reductase activity, immunoreactivity and mRNA in streptozotocin induced diabetic rats. Diabetes 38 , 1067-1071.
16 Ghahary, A., Charkrabarti, S. and Murphy, L.J. (1990) Localization of sites of synthesis and action of insulin-like growth factor-I in the rat uterus. Mol. Endocrinol. 4, 191-195.

17 Murphy, L.J., Bcll, G.I., Duckworth, M.L. and Friesen, H.G. (1987) Identification, characterization and regulation of a rat $\mathrm{CDNA}$ which encodes insulin-like growth factor-I. Endocrinology 121, 684-691.

18 Ghahary, A. and Murphy, L.J. (1989) Uterine insulin-like growth factor-I receptors: regulation by estrogen and variation through the estrous cycle. Endocrinology 125, 597-604.

19 Das, A., Pansky, B. and Budd, C. (1987) Demonstration of insulin-specific mRNA in cultured rat retinal glial cells. Invest. Ophthalmol. Vis. Sci. 28, 1800-1810.

20 Das, A., Pansky, B., Budd, G.C. and Kollaritis, C.R. (1984) Immunocytochemistry of mouse and human retina with antisera to insulin and S-100 protein. Curr. Eye Res. 3, 1397-1401.

21 Waldbig, R.J., Fletcher, R.T., Sommers, R.L. and Chader, G.F. (1988) IGF-I receptor in the bovine neural retina: structure, kinase activity and comparison with retinal insulin receptors. Exp. Eye. Res. 47, 587-607.

22 Bondy, C.A. and Lightman, S.L. (1989) Developmental and physiological pattern of aldose reductase mRNA expression in lens and retina. Mol. Endocrinol. 3. 1417-1425.

23 Ghahary, A., Murphy, L.J., Chakrabarti, S. and Sima, A.A.F. (1990) The effects of insulin and aldose reductase (AR) inhibitor treatment on AR-expression. Diabetes 39 (Suppl. 1), 61A (Abstract).

24 Hyer, S.L., Sharp, P.S., Sleightholm, M., Burrin, J.M. and Kohner, E.M. (1989) Progression of diabetic retinopathy and changes in serum insulin-like growth factor-I (IGF-I) during continuous subcutaneous insulin infusion (CSII). Horm. Metabol. Res. 21, 18-22. 